\title{
JESYA
}

JURNAL EKONOMI \& EKONOMI SYARIAH

Jurnal Ekonomi \& Ekonomi Syariah Vol 5 No 1, Januari 2022

E-ISSN : 2599-3410 | P-ISSN : 2614-3259

DOI : https://doi.org/10.36778/jesya.v5i1. 598

\section{ANALISIS LINGKUNGAN KERJA, BUDAYA ORGANISASI DAN SEMANGAT KERJA DAN PENGARUHNYA TERHADAP PRODUKTIVITAS KERJA PEGAWAI}

\author{
Alfan Madjidu \\ Program Studi Magister Manajemen, Fakultas Ekonomi, Universitas Gorontalo \\ madjidualfan@gmail.com
}

Idrus Usu

Program Studi Magister Manajemen, Fakultas Ekonomi, Universitas Gorontalo

\section{Yakup}

Program Studi Magister Manajemen, Fakultas Ekonomi, Universitas Gorontalo

\begin{abstract}
Abstrak
Tujuan Penelitian ini adalah : 1) Untuk mengetahui dan menganalisis pengaruh Lingkungan Kerja secara parsial terhadap Produktivitas Kerja Pegawai Sekretariat Daerah Provinsi Gorontalo; 2) Untuk mengetahui dan menganalisis pengaruh Budaya Organisasi secara parsial terhadap Produktivitas Kerja Pegawai Sekretariat Daerah Provinsi Gorontalo; 3) Untuk mengetahui dan menganalisis pengaruh Semangat Kerja secara parsial terhadap Produktivitas Kerja Pegawai Sekretariat Daerah Provinsi Gorontalo; 4) Untuk mengetahui dan menganalisis pengaruh Lingkungan Kerja, Budaya Organisasi dan Semangat Kerja secara simultan terhadap Produktivitas Kerja Pegawai Sekretariat Daerah Provinsi Gorontalo. Penelitian ini menggunakan metode survey dengan sampel 101 orang Pegawai. Dan data kualitatif yang digunakan dalam penelitian ini menggunakan skala likert, dan analisis yang digunakan dalam penelitian ini Analis Korelasi dan Regresi, dengan terlebih dahulu dilakukan Uji Kualitas Data Penelitian (uji validitas dan reliabilitas instrumen) dan Uji Persyaratan Analisis (Uji Normalitas Data, Uji Autokorelasi, Uji Multikolinieritas, Uji heteroskedastisitas.

Hasil Penelitian ini menunjukkan bahwa Kuatnya Pengaruh variabel Lingkungan Kerja $\left(\mathrm{X}_{1}\right)$, Budaya Organisasi $\left(\mathrm{X}_{2}\right)$, Semangat Kerja $\left(\mathrm{X}_{3}\right)$ terhadap Produktivitas Kerja Pegawai (Y) yakni sebesar 0,793. Sedangkan kontribusi secara bersama-sama (Koefisien Determinasi / R-Square) variabel $\mathrm{X}_{1}, \mathrm{X}_{2}$ dan $\mathrm{X}_{2}$ terhadap 0,628 atau 62,80\% sedangkan sisanya 37,2 \% ditentukan oleh variabel lain. Selanjutnya untuk meramalkan bagaimana keadaan (naik turunnya) variabel Semangat Kerja (Y), dapat diprediksi melalui persamaan regresi $\hat{Y}=1,020+0,346 X_{1}+0,421 X_{2}+0,516 X_{3}$. Selanjutnya Besarnya Pengaruh variabel Lingkungan Kerja secara parsial terhadap Produktivitas Kerja Pegawai sebesar 0,547 (Cukup Kuat), dan kontribusi (koefisien determinan) variabel $\mathrm{X}_{1}$ terhadap $\mathrm{Y}$ adalah sebesar 29,92 \% sedangkan sisanya 70,8\% ditentukan oleh variabel lain. Selanjutnya besarnya Pengaruh Variabel Budaya Kerja $\left(\mathrm{X}_{2}\right)$ secara parsial terhadap Semangat Kerja Pegawai (Y) adalah sebesar 0,469 (Cukup Kuat), dan kontribusi (koefisien determinan) variabel
\end{abstract}




\section{JESYA}

JURNAL EKONOMI \& EKONOMI SYARIAH

Jurnal Ekonomi \& Ekonomi Syariah Vol 5 No 1, Januari 2022

E-ISSN : 2599-3410 | P-ISSN : 2614-3259

DOI : https://doi.org/10.36778/jesya.v5i1. 598

$\mathrm{X}_{2}$ terhadap $\mathrm{Y}$ adalah sebesar 21,99\% sedangkan sisanya 78,01\% ditentukan oleh variabel lain. Selanjutnya besarnya Pengaruh Variabel Semangat Kerja $\left(\mathrm{X}_{3}\right)$ secara parsial terhadap Produktivitas Kerja Pegawai (Y) adalah sebesar 0,672 (Kuat), dan kontribusi (koefisien determinan) variabel $\mathrm{X}_{3}$ terhadap $\mathrm{Y}$ adalah sebesar 45,15 $\%$ sedangkan sisanya $54,85 \%$ ditentukan oleh variabel lain.

Kata Kunci Lingkungan Kerja, Budaya Organisasi, Semangat Kerja, Produktivitas

\section{PENDAHULUAN}

Sumber daya manusia merupakan faktor penggerak dari sebuah organisasi serta menjadi faktor utama yang dibutuhkan demi kelangsungan hidup dan untuk mencapai tujuan organisasi. Pentingnya pengelolaan terhadap sumber daya manusia disebabkan karena faktor manusia sebagai pelaku utama dalam setiap kegiatan operasional suatu organisasi. Semakin baik kemampuan SDM yang dimiliki maka akan semakin baik hasil yang dicapai, demikian pula sebaliknya, semakin rendah kualitas SDMnya maka akan semakin rendah pula hasil yang itu terjadi karena bagaimanapun canggihnya sarana dan prasarana yang dimiliki oleh suatu organisasi tanpa didukung oleh SDM yang berkualitas dan produktif akan menghambat tercapainya tujuan organisasi tersebut.

Produktivitas kerja pegawai dihasilkan berdasarkan apa yang dikerjakan oleh pegawai itu sesuai dengan tanggung jawabnya didalam mengerjakan suatu tugas yang telah ditetapkan oleh organisasi untuk menghasilkan hasil yang baik atau sesuai dengan target yang telah ditentukan oleh organisasi. Menurut Simanjuntak dalam Cipta dan Nasution (2019) produktivitas kerja pegawai mengandung pengertian adanya kemampuan pegawai untuk dapat menghasilkan barang atau jasa yang dilandasi sikap mental bahwa hari ini harus lebih baik dari hari kemarin dan esok harus lebih baik dari hari ini.

PNS merupakan aparatur negara yang mempunyai peranan dalam menentukan keberhasilan penyelenggaraan pemerintahan dan pembangunan, dan sebagai unsur Aparatur Negara dalam menjalankan roda pemerintahan dituntut untuk melaksanakan tugas, pokok dan fungsinya, serta menjunjung tinggi martabat dan citra kepegawaian demi kepentingan bangsa dan negara. oleh karena itu PNS diharapkan mempunyai kinerja yang baik, dan memiliki rasa tanggung jawab dalam menyelesaikan pekerjaan, memiliki produktivitas kerja tinggi dan berdaya guna, serta sikap dan perilakunya yang penuh dengan kesetiaan dan ketaatan kepada negara, bermoral dan bermental baik, profesional, sadar akan tanggung jawabnya sebagai pelayan publik serta mampu menjadi perekat persatuan dan kesatuan bangsa.

Berdasarkan Peraturan Gubernur Nomor 27 Tahun 2020 tentang Kedudukan, Susunan Organisasi, Tugas dan Fungsi serta Tata Kerja Sekretariat Daerah Provinsi Gorontalo, tergambar bahwa Sekretariat Provinsi Gorontalo terdiri dari 6 Biro yakni Biro Pengadaan Barang dan Jasa, Biro Organisasi, Biro Ekonomi dan Pembangunan, Biro Hukum, Biro Pemerintahan dan Kesra serta Biro Umum, yang tugasnya membantu Kepala Daerah dalam penyusunan kebijakan dan pengkoordinasian administratif terhadap pelaksanaan tugas perangkat daerah serta pelayanan 


\section{JESYA}

JURNAL EKONOMI \& EKONOMI SYARIAH

Jurnal Ekonomi \& Ekonomi Syariah Vol 5 No 1, Januari 2022

E-ISSN : 2599-3410| P-ISSN : 2614-3259

DOI : https://doi.org/10.36778/jesya.v5i1. 598

administratif (pasal 8). Untuk mendukung pelaksanaan tugas tersebut,maka setiap pegawai dituntut melaksanakan tugas dan fungsinya dengan baik dan tepat waktu.

Hasil observasi awal menunjukan bahwa tugas sebagaimana disebutkan dalam peraturan tersebut belum sepenuhnya terlaksana dengan baik oleh semua PNS, hal ini terlihat dari belum semua PNS di Sekretariat Daerah produktivitasnya optimal dalam melaksanakan tugas dan fungsinya dalam mencapai tujuan organisasi, sehingga beberapa pekerjaan tidak terlaksana tepat waktu.

Fenomena ini memperlihatkan bahwa produktivitas kerja pegawai masih perlu mendapatkan perhatian serius dari pimpinan Setda. Upaya - upaya untuk meningatkan produktivitas kerja perlu dilakukan secara terus-menerus, agar tugas pokok yang telah diamanatkan dapat dilaksanakan dengan baik, dan tepat waktu

Penurunan produktivitas kerja pegawai dipengaruhi oleh berbagai faktor, kajian teoretis maupun hasil hasil-hasil riset sebelumnya menunjukan bahwa produktivitas kerja dipengaruhi diantaranya adalah lingkungan kerja. Menurut Sedarmayanti dalam Wahyuningsih (2018) yang menyatakan bahwa lingkungan kerja secara fisik dalam arti semua keadaan yang terdapat disekitar tempat kerja, akan mempengaruhi karyawan baik secara langsung maupun secara tidak langsung. Lingkungan kerja yang dikatakan baik juga tidak terlepas dari hubungan kerja yang baik, baik itu antara karyawan dengan karyawan maupun karyawan dengan pimpinan. Berdasarkan hasil pra obsevasi, lingkungan kerja yang baik tersebut akan menimbulkan suasana yang nyaman dan menyenangkan sehingga karyawan bersemangat dalam melaksanakan pekerjaannya. Kenyamanan pada tempat kerja merupakan salah satu pendorong peningkatan produktivitas kerja karyawan, hal ini sesuai dengan pendapat Sutalaksana dkk dalam Ulum, dkk (2018) yang mengatakan bahwa manusia akan mampu melaksanakan kegiatannya dengan baik sehingga dicapai suatu hasil yang optimal, apabila diantaranya ditunjang oleh suatu kondisi lingkungan yang baik.

Selanjutnya menurut Robbins dalam Maduningtias (2019) budaya organisasi adalah sistem nilai bersama dalam suatu organisasi yang menentukan tingkatan bagaimana para karyawan melakukan kegiatan untuk mencapai tujuan organisasi. Produktivitas kerja sebagai suatu sistem dalam organisasi memerlukan upaya peningkatan agar organisasi dapat tumbuh dan berkembang, begitu juga dengan sistem yang lain seperti sistem operasional, sistem fungsional, dan sistem manajemen. Penerapan norma dan nilai yang ada pada suatu organisasi tidak dapat lepas dari pegawai yang sejatinya sebagai makhluk sosial. Cara pegawai dalam mendeskripsikan pekerjaannya, cara bekerjasama dengan yang lain, dan cara pegawai dalam bertingkah laku dapat dipengaruhi oleh budaya dalam organisasi. hal ini sesuai dengan temuan penelitian yang dilakukan oleh Antariksi dan Wasiti (2020) Budaya organisasi memiliki pengaruh yang siginifikan terhadap produktivitas kerja,

Untuk itu Selain lingkungan kerja dan budaya organisasi, peneliti juga menilai bahwa produktivitas kerja pegawai dipengaruhi oleh faktor semangat kerja. Nawawi dalam Mulyadi (2019) mengemukakan bahwa semangat kerja akan menyentuh aspek kemauan, kehendak, pikiran dan sikap dalam melaksanakan pekerjaan. Semangat kerja yang tinggi dan positif merupakan faktor yang berpengaruh pada sikap, berupa kesediaan mewujudkan cara atau metode kerja yang berdaya guna dan berhasil guna dalam meningkatkan produktivitas kerja. 


\section{JESYA}

JURNAL EKONOMI \& EKONOMI SYARIAH

Jurnal Ekonomi \& Ekonomi Syariah Vol 5 No 1, Januari 2022

E-ISSN : 2599-3410| P-ISSN : 2614-3259

DOI : https://doi.org/10.36778/jesya.v5i1. 598

Selanjutnya menurut Hadari Nawawi $(2011$; 155) Semangat Kerja yang tinggi / positif merupakan factor yang berpengaruh / berhasil guna dalam peningkatan produktivitas kerja.

Pendapat diatas, sejalan dengan temuan penelitian yang dilakukan Maydina dan Abdurrahman (2020) bahwa semangat kerja memberikan kontribusi positif terhadap peningkatan produktivitas kerja karyawan. Semangat kerja merupakan refleksi seseorang secara lebih giat melaksanakan tugas-tugasnya, sehingga pekerjaan akan dapat diselesaikan lebih cepat dan lebih baik.

Jadi dapat dikatakan bahwa semangat kerja merupakan suasana kerja yang terdapat dalam suatu organisasi yang menunjukkan sikap mental individua atau kelompok yang terdapat dalam suatu organisasi yang menunjukkan rasa kegairahan di dalam melaksanakan tugas / pekerjaan dan mendorong mereka untuk bekerja lebih baik dan lebih produktif.

\section{KAJIAN TEORI}

\section{A. Lingkungan Kerja}

Lingkungan kerja dalam suatu organisasi swasta ataupun pemerintah sangat penting untuk mendapat perhatian. Suatu kondisi lingkungan kerja dikatakan baik atau sesuai apabila manusia dapat melaksanakan kegiatan secara optimal, sehat, aman, dan nyaman. Lingkungan kerja mempunyai pengaruh langsung terhadap aktivitas para pegawai dalam melaksanakan tugas.

Menurut Sedarmayati dalam Panjaitan (2017) lingkungan kerja secara fisik dalam arti semua keadaan yang terdapat di sekitar tempat kerja, akan mempengaruhi pegawai baik secara langsung maupun secara tidak langsung. Lingkungan kerja harus didesain sedemikian rupa agar tercipta hubungan kerja yang mengikat pekerja dengan lingkungannya. Lingkungan kerja yang baik apabila karyawan atau pegawai dapat melaksanakan kegiatan secara optimal, sehat, aman dan nyaman. Lingkungan kerja yang kurang baik dapat menuntut pekerja serta waktu yang lebih banyak dan tidak mendukung diperolehnya rancangan sistem kerja yang efisien.

Adapun indikator lingkungan kerja dalam penelitian berdasarkan beberapa pendapat para ahli, dimana lingkungan kerja terdiri dari kelompok yaitu lingkungan kerja fisik dan lingkungan kerja non fisik, maka indikator pengukuran lingkungan kerja dalam penelitian ini terdiri dari (1) hubungan kerja, (2) komunikasi, (3) kebersihan, (4) penerangan ruang kerja, dan (5) keamanan kerja.

\section{B. Budaya Organisasi}

Budaya hakekatnya merupakan proses integrasi dari suatu perilaku manusia yang mencangkup pikiran, ucapan dan perbuatan dengan proses pembelajaran. Dalam kehidupannya manusia dipengaruhi oleh budaya dimana mereka berada. Hal yang sama akan terjadi di suatu organisasi atau perusahaan, bauran dari segala nilai, keyakinan dan perilaku dari setiap anggota organisasiakan membentuk budaya organisasi. Budaya organisasi menurut Robbins dalam Maduningtias (2019) adalah sistem nilai bersama dalam suatu organisasi yang menentukan tingkatan bagaimana para karyawan melakukan kegiatan untuk mencapai tujuan organisasi. Budaya organisasi merupakan suatu kepercayaan dan nilai-nilai yang menjadi falsafah utama yang dipegang teguh oleh anggota organisasi dalam menjalankan atau mengoperasionalkan kegiatan organisasi. Budaya organisasi sering kali menggambarkan dalam arti yang dimiliki bersama. Pola-pola kepercayaan, simbol- 


\section{JESYA}

JURNAL EKONOMI \& EKONOMI SYARIAH

Jurnal Ekonomi \& Ekonomi Syariah Vol 5 No 1, Januari 2022

E-ISSN : 2599-3410 | P-ISSN : 2614-3259

DOI : https://doi.org/10.36778/jesya.v5i1. 598

simbol yang berkembang dari waktu ke waktu dan fungsi sebagai perekat yang menyatukan organisasi tersebut

Lasmi dalam Antariksa dan Wasiti (2020) budaya organisasi memiliki dua atribut yang berbeda yaitu intensitas dan integritas. Intensitas merupakan batasan atau tahapan ketika para unit, pegawai menyetujui normanorma, nilai atau budaya lain yang ada pada organisasi atau perusahaan tersebut. Kemudian integritas merupakan batasan, tahapan atau konsistensi ketika unit, pegawai ikut serta memberikan budaya umum. Sedangkan menurut Suaiba, Abdullah, Suyanto, Karundeng, (2021) budaya organisasi (corporate culture) adalah sebagai aturan main yang ada dalam perusahaan yang menjadi pegangan bagi sumberdaya manusia perusahaan dalam nienjalankan kewajiban dan nilai-nilai untuk berperilaku dalam perusahaan tersebut.

Berdasarkan pendapat para ahli di atas, maka budaya organisasi merupakan seperangkat asumsi dasar dan keyakinan yang dianut oleh anggota-anggota organisasi dalam mengatasi masalah penyesuaian lingkungan ekternal dan masalah-masalah integrasi internal. Indikator penilaian budaya organisasi dalam penelitian ini terdiri : (1) Inovasi dan pengambilan resiko, (2) Perhatian yang lebih rinci, (3) Orientasi hasil, (4) Orientasi orang, (5) Keagresifan, (6) Kemantapan/stabilitas.

\section{Semangat Kerja}

Semangat kerja menggambarkan perasaan secara psikologis suasana yang dirasakan para pegawai dalam organisasi. Apabila pegawai merasa bergairah, bahagia, optimis maka kondisi tersebut menggambarkan bahwa pegawai tersebut mempunyai semangat kerja yang tinggi, tetapi apabila pegawai suka membantah, menyakiti hati, kelihatan tidak tenang maka pegawai tersebut mempunyai semangat kerja yang rendah. Munandar dalam Mafra (2017), menjelaskan semangat kerja adalah suatu sikap positif yang memandang pekerjaan sebagai hal yang penting ditandai dengan sikap melakukan pekerjaan dengan sungguh-sungguh atau optimal. Jadi semangat kerja pada hakekatnya adalah merupakan perwujudan dari moral yang tinggi. Bahkan ada yang mengidentikan atau menterjemahkan secara bebas, moral kerja yang tinggi adalah semangat dan kegairahan kerja.

Semangat kerja menurut Darmawan dalam Maydina dan Abdurrahman (2020), menjelaskan bahwa semangat kerja dapat diartikan sebagai suatu iklim atau suasana kerja yang terdapat di dalam suatu organisasi yang menunjukkan rasa kegairahan di dalam melaksanakan pekerjaan dan mendorong mereka untuk bekerja secara lebih baik dan lebih produktif. Jika semangat kerja rendah, kemungkinan partisipasi hanya akan terbatas pada apa yang diperintahkan. Sebaliknya, adanya semangat tinggi mencerminkan bahwa individu akan berpartisipasi dengan antusias dengan penuh komitmen. Semangat kerja karyawan ditunjukkan melalui pola kerja karyawan dalam menyelesaikan tugas dan tanggung jawabnya. Pegawai dengan semangat kerja tinggi akan bertanggung jawab pada pekerjaannya, serta mampu mengatasi kesulitan mengenai tugasnya.

Semangat kerja menurut Robins dalam Hendri dan Rismansyah (2016) yang juga menjadi indicator penelitian ini yakni merupakan suatu sikap positif pegawai yang ditunjukkan dengan sikap bersemangat, ceria, ramah, dan menyelesaikan tugas sampai selesai. Dengan indikator (1) sikap bekerja sama, (2) ceria, (3) ramah, dan (4) menyelesaikan tugas sampai selesai.

\section{Produktivitas Kerja}




\section{JESYA}

JURNAL EKONOMI \& EKONOMI SYARIAH

Jurnal Ekonomi \& Ekonomi Syariah Vol 5 No 1, Januari 2022

E-ISSN : 2599-3410| P-ISSN : 2614-3259

DOI : https://doi.org/10.36778/jesya.v5i1. 598

Produktivitas kerja menurut Enggana (2020) merupakan kemampuan seorang pegawai dalam melaksanakan pekerjaan untuk memperoleh hasil sesuai standar mutu yang telah ditentukan dengan batasan waktu yang lebih singkat terhadap aktivitas pekerjaan. Pernyataan ini melihat bahwa produktivitas menyentuh berbagai aspek dalam diri manusia seperti sikap, mental, etika dan keahlian sehingga dapat dijadikan sebagai pendorong dalam meningkatkan mutu untuk menjadi lebih baik setiap harinya. Hal serupa juga dikemukakan oleh Sutrisno dalam Antariksa dan Wasiti (2020) bahwa produktivitas merupakan ukuran dari efesien produktif, yang artinya perbandingan antara hasil keluaran serta masukan. Masukan lebih sering diartikan sebagai tenega kerja, sedangkan keluaran diukur melalui satuan fisik, bentuk serta nilai. Produktivitas kerja memiliki manfaat sebesar-besarnya dari sarana dan prasarana yang tersedia dengan menghasilkan output yang optimal, kalau mungkin yang maksimal. Produktivitas merupakan faktor yang sangat penting untuk kelangsungan perusahaan karena merupakan faktor kunci untuk dapat melakukan perbaikan setiap hari dan hanya tenaga kerja yang dapat meningkatkan produktivitas. Dari pemahaman diatas dapat dikatakan bahwa produktivitas menyentuh berbagai aspek dalam diri manusia seperti sikap, mental, etika dan keahlian sehingga dapat dijadikan sebagai pendorong dalam meningkatkan mutu untuk menjadi lebih baik setiap harinya.

Sinungan dalam Luturmas (2020) menyatakan bahwa produktivitas mencakup sikap mental patriotik yang memandang hari depan secara optimis dengan berakar pada keyakinan diri bahwa kehidupan hari ini adalah lebih baik dari hari kemarin dan hari esok lebih baik dari hari ini. Sikap seperti ini akan mendorong munculnya suatu kerja yang efektif dan produktif, yang sangat diperlukan dalam rangka peningkatan produktivitas kerja. Produktivitas tenaga kerja lebih ditonjolkan dan menjadi pusat perhatian bila dibandingkan dengan produktivitas modal, alat produksi dan teknologi. Kemampuan pimpinan untuk menggunakan sumber daya secara maksimal dan menciptakan sistem kerja yang optimal, akan menentukan tinggi rendahnya produktivitas kerja pegawai. Peranan manajemen sangat strategis untuk peningkatan produktivitas, yaitu dengan mengkombinasikan dan mendayagunakan semua sumber daya, menerapkan fungsi-fungsi manajemen, menciptakan sistem kerja dan pembagian kerja, menempatkan orang yang tepat pada pekerjaan yang sesuai serta menciptakan kondisi dan lingkungan kerja yang aman dan nyaman. Dengan demikian maka dapat ditentukan tinggi rendahnya produktivitas kerja pegawai dengan mempergunakan pengukuran produktivitas kerja pegawai. Menurut Luturmas (2017) pengukuran produktivitas kerja pada dasarnya digunakan untuk mengetahui sejauhmana tingkat efektivitas dan efisiensi kerja pegawai dalam menghasilkan suatu hasil. Dalam usaha untuk dapat mengukur tingkat kemampuan pegawai dalam mencapai sesuatu hasil yang lebih baik dan ketentuan yang berlaku (kesuksesan kerja).

Produktivitas pada hakekatnya meliputi sikap yang senantiasa mempunyai pandangan kearah baik yang dapat diraih esok harus lebih banyak atau lebih bermutu dari pada hasil yang diraih hari ini. Produktivitas kerja yang tinggi sangat ditentukan oleh kesadaran setiap individu atas tugas dan tanggungjawab pada pekerjaannya yang telah ditugaskan kepadanya. Menurut Sutrisno dalam Panjaitan (2017), untuk mengukur produktivitas kerja, diperlukan suatu indikator yang juga digunakan sebagai indicator penilanan variabel produktivitas dalam penelitian ini adalah 1) Kemampuan, 2) Meningkatkan hasil yang dicapai, 3) Kegairahan kerja, 4) Pengembangan diri, 5) Mutu dan 6) Efisiensi. 


\section{JESYA}

JURNAL EKONOMI \& EKONOMI SYARIAH

Jurnal Ekonomi \& Ekonomi Syariah Vol 5 No 1, Januari 2022

E-ISSN : 2599-3410 | P-ISSN : 2614-3259

DOI : https://doi.org/10.36778/jesya.v5i1. 598

\section{METODOLOGI PENELITIAN}

A. Tempat

Penelitian akan dilaksanakan di Sekretariat Daerah Provinsi Gorontalo.

\section{B. Populasi dan Sampel Penelitian}

1. Populasi

Populasi dalam penelitian ini adalah seluruh pegawai pada Sekretariat daerah Provinsi Gorontalo yang berjumlah 224 orang Pegawai (tidak termasuk pimpinan setda), dengan rincian sebagai berikut :

1. Pimpinan Setda

1. Sekretaris Daerah

7 Orang*).

2. Asisten

3. Staf Ahli Gubernur

2. Biro Umum

3. Biro Pemerintahan dan Kesejahteraan Rakyat

4. Biro Hukum

5. Biro Pengendalian Ekonomi dan Pembangunan

6. Biro Pengadaan Barang dan Jasa

7. Biro Organisasi

TOTAL

1 Orang .

3 Orang .

3 Orang .

77 Orang .

37 Orang .

25 Orang .

28 Orang .

29 Orang .

20 Orang .

223 Orang

Ket, *) Pimpinan Setda juga merupakan bagian dan PNS Biro Umum sehingga total PNS Biro Umum adalah sebesar 77 Orang +7 Orang $=84$ Orang

2. Sampel

Sejalan dengan permasalahan yang diteliti dalam penelitian ini, yaitu Analisis Lingkungan Kerja, Budaya Organisasi dan Semangat Kerja terhadap Produktivitas Kerja Pegawai pada Sekretariat Daerah Provinsi Gorontalo. Sehingga untuk menghindari adanya distorsi hasil penelitian, pengambilan sampel akan dikerjakan memakai Teknik Random Sampling.

Memperhatikan pernyataan diatas Surakmat dalam Riduwan (2004) menyarankan apabila ukuran populasi sebanyak kurang atau sama dengan 100, pengambilan sampel sekurang-kurangnya $50 \%$ dari ukuran populasi sama dengan atau lebih dari 1000, ukuran sampel diharapkan sekurang-kurangnya $15 \%$ dari ukuran populasi. Dalam penelitian ini Jumlah Populasi sebanyak

224 Orang Pegawai.Merujuk pada pendapat diatas maka penentuan jumlah sampel dapat dirumuskan sebagai berikut :

$$
\mathrm{S}=15 \%+\frac{1000-\mathrm{n}}{1000-100} \cdot(50 \%-15 \%)
$$

Dimana :

$\mathrm{S}=$ Jumlah Sampel diambil

$\mathrm{n}=$ Jumlah Anggota Populasi

$$
\begin{gathered}
S=15 \%+\frac{1000-223}{1000-100} \cdot(50 \%-15 \%) \\
S=15 \%+0,8633 \cdot(50 \%-15 \%) \\
S=15 \%+30.21 \%=45.21 \%
\end{gathered}
$$

Jadi, Jumlah sampel sebesar 223 Orang x 45, $17 \%=101$ Responden.

\section{Jenis dan Sumber Data}




\section{JESYA}

JURNAL EKONOMI \& EKONOMI SYARIAH

Jurnal Ekonomi \& Ekonomi Syariah Vol 5 No 1, Januari 2022

E-ISSN : 2599-3410 | P-ISSN : 2614-3259

DOI : https://doi.org/10.36778/jesya.v5i1. 598

1. Jenis Data

a. Data Kuantitatif

Data kuantitatif yaitu data yang berwujud dalam bentuk angka-angka yang di peroleh baik dari dokumen - dokumen maupun pengambilan data langsung pada unit analisis atau responen.

b. Data Kualitatif

Analisis kualitatif merupakan bentuk analisis yang berdasarkan dari data yang dinyatakan dalam bentuk uraian. Analisis kualitatif ini digunakan untuk membahas dan menerangkan hasil penelitian tentang berbagai gejala atau kasus yang dapat diuraikan dengan kalimat.

2. Sumber data

a. Data Primer

Yaitu data yang diperoleh langsung dari obyek penelitian baik melalui penyebaran kuisioner kepada responden.

b. Data Sekunder

Yaitu data yang bersumber dari obyek penelitian atau data hasil penelitian sebelumnya, yang dianggap berkaitan atau relevan dengan masalah yang di bahas

\section{Uji Validitas dan Reliabilitas Instrument}

1. Uji Validitas (Test of Validity)

Uji validitas digunakan untuk menilai apakah alat ukur yang digunakan benarbenar dapat mengukur variabel yang diteliti. Keakuratan validitas suatu alat test akan dapat melakukan fungsinya sebagai alat ukur yang valid. Penelitian ini pengukuran validitas digunakan aplikasi SPSS 22. Suatu butir pertanyaan dikatakan valid jika nilai r-hitung yang merupakan nilai dari Corrected ItemTotal Corelation .

2. Uji Reliabilitas (Test of Reliability)

Reliabilitas (keandalan) merupakan ukuran suatu kestabilan dan konsistensi responden dalam menjawab pertanyaan atau pernyataan yang berhubungan indikator suatu variabel yang disusun dalam bentuk kuesioner. Uji reliabilitas dilakukan terhadap seluruh butir kuisioner. Ukuran reliabilitas yang dipergunakan dalam penelitian menggunakan alfa cronback $=0,60$.

\section{E. Uji Asumsi Klasik}

1. Uji Nomalitas Data

Menurut Ghozali (2018) Uji Normalitas bertujuan untuk mengetahui apakah dalam model regresi variabel terikat dan variabel bebas memiliki distribusi normal. Uji Normalitas data yang digunakan dalam penelitian ini adalah uji Kolmogorov-Smirnov, dengan ketentuan dikatakan normal jika nilai signifikansi atau propabilitas variabel $>\alpha=0,05$ dan sebaliknya distribusi data tidak normal apabila signifikansi atau probabilitas $<0,05$

2. Uji Multikolinieritas

Menurut Ghozali (2018) Uji multikolinearitas bertujuan untuk menguji apakah model regresi ditemukan adanya korelasi antar variabel bebas (independent). Deteksi terhadap ada tidaknya multikolinearitas dapat diketahui dengan memeriksa nilai Tolerance dan VIF (Variance Inflation Factors) pada masingmasing variabel independent, apabila nilai VIF dari masing-masing variabel independent $<10$, dan nilai toleransinya $>0,1$ maka dapat dikatakan tidak terdapat gejala multikolinieritas atau hubungan yang terjadi antar variabel 


\section{JESYA}

JURNAL EKONOMI \& EKONOMI SYARIAH

Jurnal Ekonomi \& Ekonomi Syariah Vol 5 No 1, Januari 2022

E-ISSN : 2599-3410 | P-ISSN : 2614-3259

DOI : https://doi.org/10.36778/jesya.v5i1. 598

bebas dapat ditoleransi

3. Uji Heteroskesdatisitas

Menurut Ghozali (2018) bahwa Uji Heterokedatisitas bertujuan untuk menguji apakah dalam model regresi terjadi ketidaksamaan varians dari residual satu pengamatan ke pengamatan yang lain pada model regresi. Model Regresi yang baik adalah yang tidak ada gejala heterokedatisitas. Jika variance dari residual satu pengamatan ke pengamatan lain tetap, maka disebut homoskedastisitas dan jika berbeda disebut heteroskesdatisitas. Tingkat signifikasi yang digunakan adalah $5 \%$ Ketika tingkat signifikan $>5 \%$ berarti tidak terjadi gejala heterokedastisitas (metode glejser) atau bisa mendeteksi heteroskedastisitas dengan melihat ada tidaknya pola tertentu (bergelombang, melebar kemudian menyempit). Jika pola tertentu yang teratur maka terjadi heteroskesdatisitas. Dan jika tidak ada pola yang jelas, serta titiktitik menyebar diatas dan dibawah angka 0 pada sumbu Y, maka tidak terjadi heteroskesdatisitas (metode scatter plot).

4. Uji Linearitas

Menurut Ghozali (2018) Uji Linearitas digunakan untuk melihat apakah spesifikasi model yang digunakan sudah benar atau tidak. Uji ini bertujuan untuk mengetahui apakah dua variabel mempunyai hubungan yang linear atau tidak secara signifikan, uji ini digunakan sebagai prasyarat dalam analisis korelasi atau regresi linear. Pengujiannya pada SPSS menggunakan test for linearity dengan signifikasi 0,05 , dengan ketentuan apabila nilai sig deviation from linearity $>0,05$, maka terdapat hubungan yang linear antara variabel bebas dengan variabel terikat dan sebaliknya jika nilai sig $<0,05$, maka tidak terdapat hubungan yang linear antara variabel bebas dan variabel terikat.

\section{F. Metode Pengumpulan Data}

1. Penelitian Kepustakaan (Libbary Research).

Penelitian kepustakaan atau studi pustaka yaitu melakukan penelusuran teori teori dari literatur yang ada hubungannnya dengan variabel yang di teliti.

2. Studi Lapangan (Field Research)

Penelitian lapangan adalah pengumpulan data pada objek penelitian yang bertujuan untuk menyebarkan kuisioner untuk mendapatkan informasi dan data sesuai kebutuhan dengan masalah yang di teliti.

\section{G. Tehnik Analisis Data}

1. Metode kualitatif

Metode Kualitatif yaitu menguraikan dan menganalisa data-data yang ditemukan dilapangan secara deskriptif sehingga bisa membuktikan hipotesis

2. Metode Kuantitatif.

Analisis data dalam penelitian ini akan dilakukan secara kuantitatif. Analisis kuantitatif dilakukan dengan menggunakan teknik statistik untuk menguji hipotesis yaitu Regresi Ganda, Korelasi Sederhana, Korelasi berganda, Adapun Analisis data dilakukan dengan menggunakan aplikasi SPSS 22.

persamaan jalurnya (Regresi Ganda) sebagai berikut :

$\hat{\mathrm{Y}}=\mathrm{b}_{0}+\mathrm{b} 1 \mathrm{X}_{1}+\mathrm{b}_{2} \mathrm{X}_{2}+\mathrm{b}_{3} \mathrm{X}_{3}+\mathrm{e}$

Keterangan :

$\hat{Y} \quad=$ Produktivitas Kerja $\quad b_{0}=$ Nilai Konstanta 


$$
\begin{array}{ll}
X_{1} & =\text { Lingkungan Kerja } \\
X_{2} & =\text { Budaya Organisasi } \\
X_{3} & =\text { Semangat Kerja }
\end{array}
$$

$$
\begin{array}{ll}
b_{123} & =\text { Koefisien Regresi } \\
e & =\text { Pengaruh variabel lain }
\end{array}
$$

\section{HASIL PENELITIAN DAN PEMBAHASAN}

\section{A. Uji Validitas dan Reliabilitas}

1. Uji Validitas

Uji validitas butir instrumen penelitian bertujuan untuk mengukur keakuratan atau valid tidaknya suatu alat ukur/kuesioner. Suatu kuesioner dikatakan valid jika pernyataan pada butir kuesioner mampu mengungkapkan sesuatu yang akan diukur oleh kuesioner tersebut. Jenis validitas yang digunakan dalam penelitian ini adalah validitas butir instrumen. Pengujian instrumen variabel beban kerjas yaitu uji validitas butir pernyataan dengan menggunakan teknik korelasi product moment dilakukan dengan membandingkan nilai rhitung dengan rtabel. Jika rhitung $\geq$ rtabel maka butir dinyatakan valid, dan jika rhitung < rtabel maka butir dinyatakan tidak valid. Skor rtabel dengan taraf signifikan $\alpha=0,05$ pada degre of predom $(\mathrm{df})=\mathrm{n}-1$. Hasil uji kuisioner dengan 100 responden, atau $101-1=100$, nilai rtabel $=0,207$. Berdasarkan

\begin{tabular}{|c|c|c|c|c|}
\hline Variabel & No. Butir & r-hitung & r-tabel & Keterangan \\
\hline \multirow{10}{*}{$\begin{array}{l}\text { Lingkungan } \\
\text { Kerja (X1) }\end{array}$} & 1 & 0,750 & 0,1937 & Valid \\
\hline & 2 & 0,465 & 0,1937 & Valid \\
\hline & 3 & 0,377 & 0,1937 & Valid \\
\hline & 4 & 0,584 & 0,1937 & Valid \\
\hline & 5 & 0,375 & 0,1937 & Valid \\
\hline & 6 & 0,295 & 0,1937 & Valid \\
\hline & 7 & 0,646 & 0,1937 & Valid \\
\hline & 8 & 0,568 & 0,1937 & Valid \\
\hline & 9 & 0,563 & 0,1937 & Valid \\
\hline & 10 & 0,209 & 0,1937 & Valid \\
\hline \multirow{10}{*}{$\begin{array}{l}\text { Budaya } \\
\text { Organisasi } \\
\text { (X2) }\end{array}$} & 1 & 0,366 & 0,1937 & Valid \\
\hline & 2 & 0,557 & 0,1937 & Valid \\
\hline & 3 & 0,307 & 0,1937 & Valid \\
\hline & 4 & 0,714 & 0,1937 & Valid \\
\hline & 5 & 0,740 & 0,1937 & Valid \\
\hline & 6 & 0,334 & 0,1937 & Valid \\
\hline & 7 & 0,726 & 0,1937 & Valid \\
\hline & 8 & 0,830 & 0,1937 & Valid \\
\hline & 9 & 0,390 & 0,1937 & Valid \\
\hline & 10 & 0,227 & 0,1937 & Valid \\
\hline \multirow{4}{*}{$\begin{array}{c}\text { Semangat } \\
\text { Kerja (X3) }\end{array}$} & 1 & 0,714 & 0,1937 & Valid \\
\hline & 2 & 0,551 & 0,1937 & Valid \\
\hline & 3 & 0,474 & 0,1937 & Valid \\
\hline & 4 & 0,280 & 0,1937 & Valid \\
\hline
\end{tabular}
hasil pengolahan data dengan menggunakan Software SPSS diperoleh hasil pengujian validitas sebagai berikut :

Tabel 5.6.

Hasil Uji Validitas Instrumen Penelitian 


\section{JESYA}

JURNAL EKONOMI \& EKONOMI SYARIAH

Jurnal Ekonomi \& Ekonomi Syariah Vol 5 No 1, Januari 2022

E-ISSN : 2599-3410 | P-ISSN : 2614-3259

DOI : https://doi.org/10.36778/jesya.v5i1. 598

\begin{tabular}{|c|c|c|c|c|}
\hline \multirow{4}{*}{$\begin{array}{c}\text { Koduktivitas } \\
\text { Kerja (Y) }\end{array}$} & 5 & 0,587 & 0,1937 & Valid \\
\cline { 2 - 5 } & 6 & 0,370 & 0,1937 & Valid \\
\cline { 2 - 5 } & 7 & 0,538 & 0,1937 & Valid \\
\cline { 2 - 5 } & 2 & 0,529 & 0,1937 & Valid \\
\cline { 2 - 5 } & 2 & 0,641 & 0,1937 & Valid \\
\cline { 2 - 5 } & 3 & 0,668 & 0,1937 & Valid \\
\cline { 2 - 5 } & 4 & 0,475 & 0,1937 & Valid \\
\cline { 2 - 5 } & 5 & 0,391 & 0,1937 & Valid \\
\cline { 2 - 5 } & 6 & 0,438 & 0,1937 & Valid \\
\cline { 2 - 5 } & 7 & 0,362 & 0,1937 & Valid \\
\cline { 2 - 5 } & 9 & 0,245 & 0,1937 & Valid \\
\cline { 2 - 5 } & 10 & 0,449 & 0,1937 & Valid \\
\cline { 2 - 5 } & 11 & 0,454 & 0,1937 & Valid \\
\cline { 2 - 5 } & 12 & 0,1974 & 0,1937 & Valid \\
\hline
\end{tabular}

Sumber : Data Primer diolah 2021

Hasil perhitungan validitas butir instrumen lingkungan kerja yang berjumlah 10 butir memberikan hasil yang valid, skor validitas rhitung pada kolom Corrected Item-Total Correlation lebih besar dari nilai rtabel. $=0,1937$, maka seluruh butir kuisioner lingkungan kerja dapat digunakan sebagai alat ukur dalam penelitian.

\section{Uji Reliabilitas}

Hasil uji reliabilitas dengan menggunakan metode alpha cronbach's. untuk mengetahui konsistensi pengukukuran variabel penelitian. Patokan yang umumnya telah diterima secara luas adalah item pernyataan yang mendapatkan nilai alpha cronbach's lebih besar dari 0,60 dinyatakan reliabel. Hasil pengolahan dengan menggunakan Software SPSS 22 diperoleh sebagai berikut:

Tabel 5.10.

Uji Reliabilitas Instrumen Penelitian

\begin{tabular}{|l|c|c|c|}
\hline \multicolumn{1}{|c|}{ Variabel } & Koefisien Reliabilitas & Alpa Cronbach & Keterangan \\
\hline Lingkungan Kerja $\left(\mathrm{X}_{1}\right)$ & 0,642 & 0,60 & Reliable \\
\hline Budaya Oganisasi $\left(\mathrm{X}_{2}\right)$ & 0,714 & 0,60 & Reliable \\
\hline Semangat Kerja $\left(\mathrm{X}_{3}\right)$ & 0,603 & 0,60 & Reliable \\
\hline Produktivitas Kerja $(\mathrm{Y})$ & 0,614 & 0,60 & Reliable \\
\hline
\end{tabular}

Sumber : Data penelitian sudah diolah 2021 (Lampiran 4)

Dari keempat variable yang di teliti, nilai alpha cronbach's rata - rata berada di atas 0,60 ini berarti bahwa seluruh item butir pernyataan dari setiap variabel dinyatakan reliabel.

\section{B. Uji Asumsi Klasik.}

\section{Uji Normalitas Data}

Model regresi yang baik adalah yang memiliki distribusi normal atau mendekati normal. Untuk itu diperlukan uji normalitas, yang dimaksudkan untuk menguji apakah variabel independen dan variabel dependen dalam 


\section{JESYA}

JURNAL EKONOMI \& EKONOMI SYARIAH

Jurnal Ekonomi \& Ekonomi Syariah Vol 5 No 1, Januari 2022

E-ISSN : 2599-3410 | P-ISSN : 2614-3259

DOI : https://doi.org/10.36778/jesya.v5i1. 598

model regresi mempunyai distribusi normal atau tidak. Uji normalitas bertujuan untuk menguji apakah variabel dalam model regresi variabel pengganggu atau residual memiliki distribusi normal. Dalam penelitian ini Uji Normalitas dilakukan dengan menggunakan analisis statistik KolmogorovSimirnov (K-S), dengan ketentuan Nilai signifikansi atau probabilitas $<0,05$ maka distribusi data tidak normal dan sebaliknya jika Nilai signifikansi atau probabilitas $>0,05$ maka distribusi data adalah normal.

Tabel 5.11.

One-Sample Kolmogorov-Smirnov Test

\begin{tabular}{|ll|r|}
\hline & & Unstandardized Residual \\
\hline $\mathrm{N}$ & & 101 \\
Normal Parameters & Mean & .0000000 \\
& Std. Deviation & 1.58029777 \\
Most Extreme Differences & Absolute & .059 \\
& Positive & .046 \\
& Negative & -.059 \\
Test Statistic & & .059 \\
Asymp. Sig. (2-tailed) & & .200 \\
\hline
\end{tabular}

a. Test distribution is Normal.

b. Calculated from data.

c. Lilliefors Significance Correction.

d. This is a lower bound of the true significance.

Sumber : Data Primer diolah 2021 (Lampiran 5)

Hasil pengujian normalitas data menunjukan bahwa Nilai Asymp Sig (2 tailed) Nilainya $>0,05$, maka distribusi data adalah normal, sehingga data memenuhi persyaratan uji normalitas data.

2. Uji Multikolinieritas

Uji multikolieritas dilakukan untuk mengetahui apakah tidak terjadi hubungan linier yang sempurna atau dapat pula dikatakan bahwa antar variabel bebas tidak saling berkaitan. Jika terjadi kolieritas, maka dinamakan terdapat problem multikolinieritas. Model regresi yang baik sebaiknya tidak terjadi korelasi di antara variabel independen. Pengujiannya dilakukan dengan membandingkan nilai tolerance lebih besar dari 0,1 dan nilai VIF kurang dari 10. maka terjadi multikolieritas.

Tabel 5.12

Uji Multikolieritas

\begin{tabular}{|c|l|c|c|c|}
\hline \multirow{2}{*}{ Model } & \multicolumn{2}{|c|}{ Collinearity Statistics } & \multirow{2}{*}{ Keputusan } \\
\cline { 3 - 4 } & & Tolerance & VIF & \\
\hline \multirow{3}{*}{1} & Lingkungan Kerja & .665 & 1.503 & Bebas Multikol \\
\cline { 3 - 4 } & Budaya Organisasi & .933 & 1.072 & Bebas Multikol \\
\cline { 2 - 4 } & Semangat Kerja & .635 & 1.575 & Bebas Multikol \\
\hline
\end{tabular}

Sumber : Data Primer diolah 2021 (Lampiran 6)

Berdasarkan tabel di atas, hasil perhitungan nilai tolerance semua variabel lebih dari dari 0,10 yang berarti tidak ada korelasi antar variabel independen. Hasil perhitungan nilai Variance Inflation Factor (VIF) juga menunjukkan hal yang sama tidak ada satu variabel independen yang memiliki nilai VIF lebih dari 10. Jadi dapat disimpulkan bahwa tidak ada multikolinearitas antar variabel independen dalam model regresi.

\section{Uji Heteroskesdatisitas}




\section{JESYA}

JURNAL EKONOMI \& EKONOMI SYARIAH

Jurnal Ekonomi \& Ekonomi Syariah Vol 5 No 1, Januari 2022

E-ISSN : 2599-3410 | P-ISSN : 2614-3259

DOI : https://doi.org/10.36778/jesya.v5i1. 598

Uji Heterokedatisitas bertujuan untuk menguji apakah dalam model regresi terjadi ketidaksamaan varians dari residual satu pengamatan ke pengamatan yang lain. Jika variance dari residual satu pengamatan ke pengamatan lain tetap, maka disebut homoskedastisitas dan jika berbeda disebut heteroskesdatisitas. Untuk mendeteksi heteroskedastisitas dapat dilakukan dengan melihat ada tidaknya pola tertentu (bergelombang, melebar kemudian menyempit). Jika pola tertentu yang teratur maka terjadi heteroskesdatisitas. Dan jika tidak ada pola yang jelas, serta titiktitik menyebar diatas dan dibawah angka 0 pada sumbu Y, maka tidak terjadi heteroskesdatisitas.

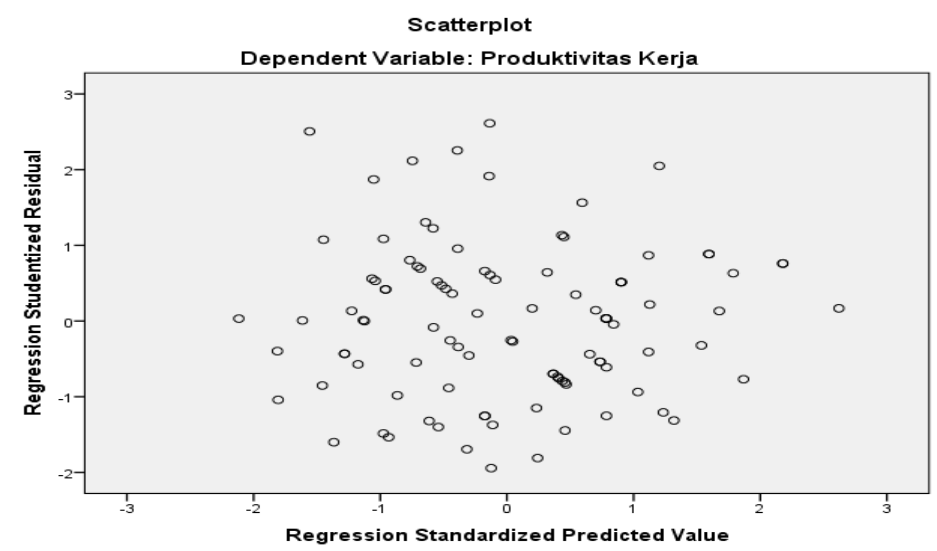

Gambar. 5.1. Hasil Uji Heterokedatisitas

Sumber : Data Primer diolah 2021

Dari hasil grafik yang disajikan diatas memperlihatkan bahwa titik-titik menyebar secara acak serta tersebar diatas maupun dibawah angka 0 pada sumbu Y, serta tidak mempunyai pola yang jelas atau tidak membentuk suatu pola. Untuk itu dapat disimpulkan bahwa tidak terjadi heteroskedastisitas pada model regresi, sehingga model regresi layak dipakai sebagai prediksi.

\section{Uji Linearitas}

Uji ini untuk mengetahui apa terdapat hubungan yang linear antara variabel dependen dan variabel independent, diaman uji ini digunakan sebagai prasyarat dalam analisis korelasi atau regresi Linear. Uji dalam penelitian ini menggunakan Test for Linearity dengan signifikansi 0,05, dengan ketentuan jika nilai Sig deviation for linearity $>0,05$, maka terdapat hubungan yang linear antara variabel dependen dan variabel independent dan sebaliknya maka tidak terdapat hubungan yang linear.

Hasil Uji Linear menunjukkan data sebagai :

Tabel 5.13.

Uji Linearitas Instrumen Penelitian

\begin{tabular}{|l|c|c|}
\hline Variabel Dependen vs independent & $\begin{array}{c}\text { Deviation } \\
\text { from } \\
\text { Linearity }\end{array}$ & Keterangan \\
\hline Produktivitas Kerja vs Lingkungan Kerja & 0,904 & Linear \\
\hline Produktivitas Kerja vs Budaya Org. & 0,089 & Linear \\
\hline Produktivitas Kerja vs Semangat Kerja & 0,207 & Linear \\
\hline
\end{tabular}




\section{JESYA}

JURNAL EKONOMI \& EKONOMI SYARIAH

Jurnal Ekonomi \& Ekonomi Syariah Vol 5 No 1, Januari 2022

E-ISSN : 2599-3410 | P-ISSN : 2614-3259

DOI : https://doi.org/10.36778/jesya.v5i1. 598

Sumber : Data penelitian sudah diolah 2021

Berdasarkan tabel 5.13 di atas, terlihat bahwa seluruh nilai Deviation from Linearity variabel Dependen vs variabel dependen $>0,05$ terdapat hubungan yang linear antara variabel dependen dan variabel independent

\section{Analisis Data}

\section{Analisis Linear Regresi Berganda}

Metode kuantitatif yang digunakan dalam penelitian ini adalah menggunakan analisis regresi linier berganda untuk menganalisa pengaruh variabel independen terhadap variabel dependen. Sebagaimana tergambarkan pada table berikut ini

Tabel 5.17

Hasil Analisis Regresi Berganda

Coefficients $^{\mathrm{a}}$

\begin{tabular}{|c|c|c|c|c|c|c|}
\hline \multirow{2}{*}{\multicolumn{2}{|c|}{ Model }} & \multicolumn{2}{|c|}{$\begin{array}{l}\text { Unstandardized } \\
\text { Coefficients }\end{array}$} & \multirow{2}{*}{$\begin{array}{c}\begin{array}{c}\text { Standardize } \\
d \\
\text { Coefficients }\end{array} \\
\text { Beta }\end{array}$} & \multirow[t]{2}{*}{$\mathrm{T}$} & \multirow[t]{2}{*}{ Sig. } \\
\hline & & $\mathrm{B}$ & Std. Error & & & \\
\hline \multirow[t]{4}{*}{1} & (Constant) & 1.020 & 3.569 & & .286 & .776 \\
\hline & $\begin{array}{l}\text { Lingkungan } \\
\text { Kerja }\end{array}$ & .346 & .084 & .314 & 4.138 & .000 \\
\hline & $\begin{array}{l}\text { Budaya } \\
\text { Organisasi }\end{array}$ & .421 & .071 & .381 & 5.952 & .000 \\
\hline & Semangat Kerja & .516 & .097 & .413 & 5.319 & .000 \\
\hline
\end{tabular}

a. Dependent Variable: Produktivitas Kerja

Sumber : Data Primer diolah 2021

Berdasarkan table diatas di peroleh persamaan regresinya sebagai berikut :

$\hat{\mathrm{Y}}=\mathrm{a}+\mathrm{b}_{1} \mathrm{X}_{1}+\mathrm{b}_{1} \mathrm{X}_{2}+\mathrm{b}_{1} \mathrm{X}_{3}$

$\hat{Y}=1,020+0,346 X_{1}+0,421 X_{2}+0,516 X_{3}$

Dari persamaan tersebut dapat dijelaskan sebagai berikut:

a. Nilai konstanta $(a)=1,020$, memberikan arti jika lingkungan kerja $\left(X_{1}\right)$, budaya organisasi $\left(\mathrm{X}_{2}\right)$, dan semangat kerja $\left(\mathrm{X}_{3}\right)$ bernilai 0 , maka produktivitas kerja pegawai akan konstan pada angka 1,020.

b. Koefisien regresi lingkungan kerja $\left(b_{1}\right)=0,346$, memberikan makna bahwa setiap peningkatan nilai pada variabel lingkungan kerja sebesar satu satuan akan diikuti dengan adanay peningkatan produktivitas kerja pegawai sebesar 0,346, dengan asumsi variabel independen lainnya dalam keadaan tetap.

c. Koefisien regresi budaya organisasi $\left(b_{2}\right)=0,421$, memberikan makna bahwa setiap peningkatan nilai variabel budaya organisasi sebesar satu satuan akan diikuti dengan adanya peningkatan produktivitas kerja pegawai sebesar 0,421 , dengan asumsi variabel independen lainnya dalam keadaan tetap.

d. Koefisien regresi semangat kerja $\left(b_{3}\right)=0,516$, memberikan makna bahwa setiap peningkatan nilai variabel semangat kerja sebesar satu satuan akan diikuti dengan adanya peningkatan produktivitas kerja pegawai sebesar 0,516 , dengan asumsi variabel independen lainnya dalam keadaan tetap.

\section{Pembahasan}




\section{JESYA}

JURNAL EKONOMI \& EKONOMI SYARIAH

Jurnal Ekonomi \& Ekonomi Syariah Vol 5 No 1, Januari 2022

E-ISSN : 2599-3410| P-ISSN : 2614-3259

DOI : https://doi.org/10.36778/jesya.v5i1. 598

\section{A. Pengaruh Lingkungan Kerja secara parsial terhadap Produktivitas Kerja}

Hasil Penelitian ini menunjukkan bahwa Korelasi antara Variabel Lingkungan Kerja $\left(\mathrm{X}_{1}\right)$ dan Produktivitas Kerja $(\mathrm{Y})$ adalah cukup kuat dan Signifikan yakni sebesar 0,547, sedangkan kontribusi (koefisien determinan) Variabel $\mathrm{X}_{1}$ terhadap $\mathrm{Y}$ adalah sebesar $29,92 \%$ sedangkat sisanya 70,08 \% ditentukan oleh variabel lain. Selanjutnya Hasil uji t menunjukkan hipotesis pertama diterima artinya Lingkungan Kerja $\left(\mathrm{X}_{1}\right)$ secara parsial berpengaruh signifikan terhadap Produktivitas Kerja (Y) pegawai pada Sekretariat Daerah Provinsi Gorontalo. Itu artinya Produktivitas kerja pegawai dapat ditingkatkan dengan memperbaiki Lingkungan Kerja.

Lingkungan kerja yang dimaksudkan adalah lingkungan dimana pegawai melakukan pekerjaannya sehari-hari. Lingkungan kerja mencerminkan segala sesuatu yang ada di sekitar pekerja dan dapat mempengaruhi dirinya dalam menjalankan tugas-tugas yang dibebankan. Faktor-faktor yang termasuk lingkungan kerja yang harus diketahui dan diperhatikan yang berpengaruh besar terhadap semangat kegairahan kerja antara lain pewarnaan, kebersihan, pertukaran udara, penerangan, keamanan dan kebisingan. Suatu lingkungan kerja di katakan baik atau sesuai apabila tenaga kerja dalam melaksanakan kegiatannya secara optimal, sehat, nyaman, dan nyaman. lingkungan kerja merupakan keadaan sekitar tempat kerja baik secara fisik maupun non fisik yang dapat memberikan kesan yang menyenangkan, mengamankan, menentramkan, dan betah kerja.

Hasil temuan ini sejalan dengan pendapat yang dikemukakan oleh Sunyoto dalam Saputra, dkk (2020) lingkungan kerja adalah segala sesuatu yang ada disekitar karyawan atau pegawai yang dapat mempengaruhi dalam menjalankan tugas yang dikerjakan yaitu peningkatan produktivitas. Lingkungan kerja baik yang bersifat fisik maupun non fisik dimana pegawai pada suatu organisasi dalam melaksanakan kegiatan operasionalnya didukung dengan fasilitas yang memadai yang dapat mempelancar pelaksanaan pekerjaan. Lingkungan kerja meliputi (1) hubungan kerja, (2)komunikasi, (3)kebersihan, (4)penerangan ruang kerja, dan (5) keamanan kerja.

\section{B. Pengaruh Budaya Organisasi secara parsial terhadap Produktivitas Kerja}

Hasil Penelitian ini menunjukkan bahwa Korelasi antara Variabel Budaya Organisasi $\left(\mathrm{X}_{2}\right)$ dan Produktivitas Kerja (Y) adalah cukup kuat yakni sebesar 0,469 sedangkan kontribusi (koefisien determinan) Variabel $\mathrm{X}_{2}$ terhadap $\mathrm{Y}$ adalah sebesar 21,99\% sedangkan sisanya 78,01\% ditentukan oleh variabel lain.

Selanjutnya Hasil uji t menunjukkan Hipotesis Kedua diterima artinya Budaya Organisasi $\left(\mathrm{X}_{2}\right)$ secara parsial berpengaruh signifikan terhadap Produktivitas Kerja (Y) pegawai pada Sekretariat Daerah Provinsi Gorontalo.

Produktivitas kerja pegawai dapat ditingkatkan dengan menerapkan dan memperaktekan budaya organisasi sesuai norma-norma atau aturan yang berlaku atau yang dianut. Budaya organisasi merupakan sistem nilai bersama dalam suatu organisasi yang menentukan aktivitas atau perilaku para pegawai melakukan kegiatan untuk mencapai tujuan organisasi. Budaya organisasi mencerminkan suatu kepercayaan dan nilai-nilai yang menjadi falsafah utama yang dipegang teguh oleh anggota organisasi dalam melaksanakan tugasnya. Budaya organisasi berhubungan dengan kebiasaan yang harus dipatuhi dalam melaksanakan tugas yang tidak bisa dilanggar, jika terjadi pelanggaran, maka ada konsekuensi yang harus dipertanggungjawabkan, karena budaya didalamnya terdapat aturan - aturan 


\section{JESYA}

JURNAL EKONOMI \& EKONOMI SYARIAH

Jurnal Ekonomi \& Ekonomi Syariah Vol 5 No 1, Januari 2022

E-ISSN : 2599-3410 | P-ISSN : 2614-3259

DOI : https://doi.org/10.36778/jesya.v5i1. 598

yang harus dipatuhi atau ditaati. Budaya organisasi menjadi ciri khas atau identitas suatu organisasi yang membedakannya dengan organisasi lain dalam memperkuat eksistensi organisasi maupun pengikat antar anggota di dalamnya. Budaya organisasi berperan untuk menentukan arah organisasi, mengarahkan tentang apa yang boleh dan tidak boleh dilakukan, bagaimana mengalokasikan dan mengatur sumber daya organisasional maupun sebagai alat untuk menghadapi masalah dan peluang yang datang dari lingkungan organisasi.

Temuan dalam penelitian ini sejalan dengan pendapat Robins dalam Lestari (2020) yang menyatakan budaya sebagai sistem makna bersama yang dianut oleh anggota - anggota yang membedakan organisasi dengan organisasi - organisasi yang lain, yang dapat meningkatkan produktivitas kerja. Budaya organisasi dijadikan sebagai alat untuk menentukan arah organisasi, mengarahkan apa yang boleh dilakukan dan yang tidak boleh dilakukan, bagaimana mengalokasikan sumber daya dan mengelola sumber daya organisasional, juga sebagai alat untuk menghadapi masalah peluang dari lingkaran internal maupun eksternal. Budaya organisasi terdiri dari : Inovasi dan pengambilan resiko, yaitu kadar seberapa jauh karyawan didorong untuk inovatif dan mengambil resiko, perhatian yang lebih rinci atau detail, yaitu kadar seberapa jauh pegawai diharapkan mampu menunjukkan ketepatan, analisis dan perhatian yang rinci/detail, orientasi hasil, yaitu kadar seberapa jauh pimpinan berfokus pada hasil atau output dan bukannya pada cara mencapai hasil itu, orientasi orang, yaitu kadar seberapa jauh keputusan manajemen turut mempengaruhi orang- orang yang ada dalam organisasi, Orientasi tim, yaitu kadar seberapa jauh pekerjaan disusun berdasarkan tim dan bukannya perorangan, keagresifan, yaitu kadar seberapa jauh pegawai agresif dan bersaing, bukannya daripada bekerja sama, kemantapan/stabilitas, yaitu kadar seberapa jauh keputusan dan tindakan organisasi menekankan usaha untuk mempertahankan status quo.

\section{Pengaruh Semangat Kerja secara parsial terhadap Produktivitas Kerja}

Hasil Penelitian ini menunjukkan bahwa Korelasi antara Variabel Semangat Kerja $\left(\mathrm{X}_{3}\right)$ dan Produktivitas Kerja (Y) adalah kuat yakni sebesar 0,672 sedangkan kontribusi (koefisien determinan) Variabel $\mathrm{X}_{2}$ terhadap Y adalah sebesar 45,15\% sedangkan sisanya 54,85\% ditentukan oleh variabel lain.

Selanjutnya Hasil uji t menunjukkan Hipotesis Ketiga diterima artinya Semangat Kerja $\left(\mathrm{X}_{3}\right)$ dan Produktivitas Kerja (Y) berpengaruh positif dan signifikan terhadap Produktivitas Kerja (Y) pegawai pada Sekretariat Daerah Provinsi Gorontalo. Itu artinya Produktivitas kerja pegawai dapat ditingkatkan dengan meningkatkan semangat kerja.

Temuan penelitian ini sejalan dengan pendapat Purwanto dalam Assagaf \& Dotulong (2015) semangat kerja merupakan sesuatu yang membuat orang-orang senang mengabdi kepada pekerjaannya, dimana kepuasaan bekerja dan hubunganhubungan kekeluargaan yang menyenangkan menjadi bagian dari dirinya. Untuk mendapatkan pegawai yang lebih bersemangat dan tidak mudah jenuh maka organisasi harus memperhatikan keinginan dan kemampuan pegawai yaitu keinginan untuk mengembangkan diri dengan cara memberikan pekerjaan yang sesuai dengan keahliannya.

\section{Kesimpulan}




\section{JESYA}

JURNAL EKONOMI \& EKONOMI SYARIAH

Jurnal Ekonomi \& Ekonomi Syariah Vol 5 No 1, Januari 2022

E-ISSN : 2599-3410| P-ISSN : 2614-3259

DOI : https://doi.org/10.36778/jesya.v5i1. 598

Berdasarkan hasil analisis pada bab Sebelumnya, maka dapat disimpulkan sebagai berikut:

1. Lingkungan kerja (X1) berpengaruh signifikan terhadap produktivitas kerja pegawai pada sekretariat Daerah Provinsi Gorontalo. Hasil menunjukan bahwa untuk meningkatkan produktivitas kerja pegawai, maka lingkungan kerja harus, selalu diperhatikan dan dilengkapi sesuai kebutuhan pegawai, baik yang bersifat fisik maupun non fisik.

2. Budaya Organisasi (X2) berpengaruh signifikan terhadap produktivitas kerja pegawai pada sekretariat Daerah Provinsi Gorontalo. Hasil menunjukan bahwa untuk meningkatkan produktivitas kerja pegawai, maka budaya organisasi yang harus diterapkan dalam pelaksanaan tugas. Karena budaya organisasi menjadi pembeda dengan organisasi lain, yang dapat dijadikan sebagai keunggulan organisasi.

3. Semangat kerja (X3) berpengaruh signifikan terhadap produktivitas kerja pegawai pada sekretariat Daerah Provinsi Gorontalo. Hasil menunjukan bahwa untuk meningkatkan produktivitas kerja pegawai, maka semangat kerja pegawai harus selalu ditingkatkan, karena semangat kerja menjadi kekuatan dalam meningkatkan produktivitas kerja pegawai.

\section{DAFTAR PUSTAKA}

Ahmadi. Edy Anas, Herwidyaningtyas, Fristina Bhakti, Fatimah. Siti. 2020. The Influence Of Organizational Culture, Work Motivation, And Job Satisfaction On Management Lecturer Performance (Empirical Study At Higher Education In The Residency Of Bojonegoro. Journal Of Industrial Engineering \& Management Research. Jilid 1. Terbitan 3 Halaman 76-83

Antariksa, Yani., Wasiti, 2019. Pengaruh Budaya Organisasi Dan Disiplin Kerja

Terhadap Kinerja Karyawan Dengan Produktivitas Kerja Sebagai Variabel Intervening Pada Pt. Intercallin (Battery ABC) Jurnal Ekonomi Bisnis Indonesia, Volume 15 No. 1 Juni 2020

Assagaf, Shannon Cecilia Y., Dotulong, Lucky O.H., 2015. Pengaruh Disiplin, Motivasi Dan Semangat Kerja Terhadap Produktivitas Kerja Pegawai Dinas Pendapatan Daerah Kota Manado. Jurnal EMBA, Vol.3 No.2 Juni 2015

Baiti,Khairunisa Nur., Djumali., Eny Kustiyah. 2020. Produktivitas Kerja Karyawan Ditinjau Dari Motivasi, Disiplin Kerja dan Lingkungan Kerja Pada Pt. Iskandar Indah Printing Textile Surakarta. Edunomika - Vol. 04, No. 01 (Februari 2020)

Cipta, Guruh Hendra., Nasution, Farida Hanum. 2019. Pengaruh Budaya Organisasi Dan Disiplin Kerja Terhadap Produktivitas Aparatur Sipil Negara Pada Dinas Perhubungan Provinsi Sumatera Utara. Jurnal Publik Reform UNDHAR MEDAN. Edisi 5 Januari-Juni 2019

Enggana, Juli. 2017. Pengaruh Budaya Organisasi Dan Disiplin Kerja Terhadap Produktivitas Kerja Karyawan Pada Pt Bank Mestika Dharma, Tbk. Cabang Pematangsiantar. Jurnal Sultanist. Vol. 6, No. 1, Juni 2017

Ginting, Nurmaidah., Ika Theresia Tampubolon., Mona Parhusip., Syukur Selamat Mendrofa. 2020. Pengaruh Motivasi, Komunikasi, Dan Semangat Kerja Terhadap Produktivitas Kerja Karyawan Pada PT.Perkebunan Nusantara Iii Medan. Jurnal Aksara Public Volume 4 Nomor 3 Edisi Agustus 2020

Hasibuan, Malayu. SP. 2015. Manajemen Sumber Daya Manusia. Jakarta: Bumi Aksara. 


\section{JESYA}

JURNAL EKONOMI \& EKONOMI SYARIAH

Jurnal Ekonomi \& Ekonomi Syariah Vol 5 No 1, Januari 2022

E-ISSN : 2599-3410 | P-ISSN : 2614-3259

DOI : https://doi.org/10.36778/jesya.v5i1. 598

Hanggraeni, 2017. Manajemen Sumber Daya Manusia. Jakarta. Fakultasa Ekonomi Universitas Indonesia

Hendri, Edduar., Rismansyah. Pengaruh Kepuasan Kerja Dan Semangat Kerja Terhadap Produktivitas Kerja Karyawan Pada PT. Selapan Jaya Ogan Komering Ilir. Jurnal Media Wahana Ekonomika, Vol 13, No.1, April 2016

Kaswan, 2017. Manajemen Sumber Daya Manusia Untuk Keunggulan Bersaing Organisasi. Yogyakarta. Graha Ilmu

Lestari, Nur Hidayah Indah. 2020. Pengaruh Kompensasi Dan Budaya Organisasi Terhadap Produktivitas Dengan Mediasi Motivasi Kerja (Studi Kasus Pada PT. Hutan Rindang Banua). Jbs (Jurnal Berbasis Sosial). Vol 1, No 2, Desember 2020

Laili, Wakhidah Nur Rohmatul. 2018. Pengaruh Budaya Organisasi Syariah Terhadap Produktivitas Kerja Karyawan. Jurnal Ekonomi Islam Volume 1 Nomor 1, Tahun 2018

Luturmas, Join Rachel. 2017. Pengaruh Budaya Kerja dan Kepuasan Kerja terhadap Produktivitas Kerja Karyawan AJB Bumiputera 1912 Cabang Ambon. Jurnal Penelitian Manajemen Terapan (PENATARAN) Vol. 2 No. 2 (2017)

Luthans, Fred, 2016. Perilaku organisasi. McGraw-Hill: Intemasional Book Company Maduningtias, Lucia. 2019. Pengaruh Lingkungan Kerja Dan Budaya Organisasi Terhadap Produktivitas Karyawan Pada PT. L'ESSENTIAL. Jurnal Ilmiah, Manajemen Sumber Daya Manusia JENIUS. Vol. 2, No. 3, Mei 2019

Maydina, Alifia Anisa., Abdurrahman, Dudung, 2020. Pengaruh Semangat Kerja dan Disiplin Kerja terhadap Produktivitas Karyawan PT. Lintas Mediatama Bandung. Prosiding Manajemen .Volume 6, No. 1, Tahun 2020

Mafra, Nisa' Ulul. 2017. Pengaruh Kepuasan Kerja Dan Semangat Kerja Terhadap Produktivitas Kerja Pegawai Pada Distrik Navigasi Kelas I Palembang. Jurnal Ecoment Global. Volume 2 Nomor 2 Edisi Agustus 2017

Muliadi. 2019. Peningkatan Produktivitas Kerja Karyawan Melalui Semangat Kerja Suatu Penelitian pada Koperasi Warga Makmur Unit Marisa Kabupaten Pohuwato. TASAMUH: JURNAL STUDI ISLAM. Volume 11, Nomor 1, April 2019

Nainggolan, Hermin., Intira Feni. 2019. Pengaruh Budaya Organisasi, Pengembangan Kecerdasan Emosi Dan Konflik Kerja Terhadap Produktivitas Kerja Karyawan Pt. Borneo Citra Persada Mandiri Di Balikpapan. Jurnal Ilmiah Methonomi. Volume 5 Nomor 1 (2019)

Nurrrulloh, Mohammad, 2015. Pengaruh Lingkungan Kerja Terhadap Produktivitas Pegawai Dinas Pekerjaan Umum Provinsi Kalimantan Timur.

Panjaitan, Maludin. 2017. Pengaruh Lingkungan Kerja Terhadap Produktivitas Kerja Karyawan. Jurnal Manajemen Vol 3. No. 2. JULI - DESEMBER 2017

Rivai, Veithzal., Muliaman Darmansyah Hadad dan H. Mansyur Ramly. 2016. Kepemimpinan dan Perilaku Organisasi. Edisi Keempat. Jakarta: PT. RajaGrafindo Persada.

Saputra, Edwin Faisal., Meilaty Finthariasari., Taufik Bustami, 2020. Pengaruh Lingkungan Kerja Dan Budaya Organisasi Terhadap Produktivitas Kerja Karyawan. Jurnal Etrepreneur dan Manajemen Sains (JEMS). Volume 1 Nomor 2 Juli 2020 


\section{JESYA}

JURNAL EKONOMI \& EKONOMI SYARIAH

Jurnal Ekonomi \& Ekonomi Syariah Vol 5 No 1, Januari 2022

E-ISSN : 2599-3410| P-ISSN : 2614-3259

DOI : https://doi.org/10.36778/jesya.v5i1. 598

Safi'i, Siti Zulaiha. 2015. Pengaruh Budaya Organisasi Dan Komitmen Organisasi Terhadap Turnover Karyawan Pada PT. Massindo Sinar Pratama. Tbk Manado. Jurnal Emba Vol.3 No.1 Maret 2015

Sagita, Alinvia Ayu., Heru Susilo., Muhammad Cahyo W.S. 2018. Pengaruh Budaya Organisasi Terhadap Kinerja Karyawan Dengan Motivasi Kerja Sebagai Variabel Mediator (Studi Pada PT Astra Internasional, Tbk-Toyota (Auto2000) Cabang Sutoyo Malang). Jurnal Administrasi Bisnis (JAB)|Vol. 57 No.1 April 2018

Sedarmayanti, 2016. Sumber Daya Manusia dan Produktivitas Kerja, Ilham Jaya, Bandung.

Senata, I Wayan., I Made Nuridja., Kadek Rai Suwena. Pengaruh Lingkungan Kerja Terhadap Produktivitas Kerja Karyawan Ud. Kembang Sari Kabupaten Badung. Vol: 4 No: 1 Tahun: 2014

Suaiba, H. R., Abdullah, J., Suyanto, M. A., \& Karundeng, D. R. (2021). Pengaruh Budaya Organisasi, Motivasi Dan Lingkungan Kerja Terhadap Kinerja Pegawai Pada Kantor Perwakilan Bank Indonesia Provinsi Gorontalo. Jurnal Ilmiah MEA (Manajemen, Ekonomi, \& Akuntansi), 5(3), 1545-1568.

Suwatno dan Priansa, 2016. Manajemen Sumber Daya Manusia. Bandung. Alfabeta

Sofian, Edi., Julkarnain. 2019. Pengaruh Pengalaman Kerja Dan Semangat Kerja Terhadap Kinerja Karyawan di PT. Dutagriya Sarana Medan. Jurnal Riset Manajemen \& Bisnis (Jrmb), Vol.4 No.2 Nopember 2019

Ulum, Alvin Efendi Khoirul., Suyadi, Bambang., Wiwin Hartanto, 2018. Pengaruh Lingkungan Kerja Dan Keterampilan Kerja Terhadap Produktivitas Kerja Karyawan Pada Pabrik Rokok Gagak Hitam Kecamatan Maesan Kabupaten Bondowoso. Jurnal Pendidikan Ekonomi. Volume 12 Nomor 2 (2018)

Wasti, 2017. Pengaruh Kompetensi Dan Semangat Kerja Terhadap Produktivitas Kerja Di Kantor Kecamatan Long Hubung Kabupaten Mahakam Ulu. Ejournal Pemerintahan Integratif, 2017, 5 (2)

Wahyuningsih, Sri. 2018. Pengaruh Lingkungan Kerja Terhadap Produktivitas Kerja. Jurnal Warta Edisi : 57 Juli 2018

Wiwik Sudarmayanti, 2015. Pengaruh Budaya Organisasi Terhadap Kinerja Pegawai Kantor Camat Loa Kulu Kabupaten Kutai Kartanegara. E-journal Administrasi Negara, 3, (5) 2015: 1952-1966

(gorontaloprov.go.id/pimpinan-opd-gorontalo-sepakati-6-nilai-budaya-kerja/) 